ARTICLE

DOI: $10.1038 / s 41467-018-06973-w$

\title{
Transient hydrodynamic effects influence organic carbon signatures in marine sediments
}

\author{
Clayton R. Magill,2, Blanca Ausín', Pascal Wenk¹, Cameron Mclntyre (10 1,3,7, Luke Skinner ${ }^{4}$, \\ Alfredo Martínez-García (ib) ${ }^{1,5}$, David A. Hodell ${ }^{4}$, Gerald H. Haug ${ }^{1,5}$, William Kenney (i) ${ }^{6}$ \& Timothy I. Eglinton (i) ${ }^{1}$
}

Ocean dynamics served an important role during past dramatic climate changes via impacts on deep-ocean carbon storage. Such changes are recorded in sedimentary proxies of hydrographic change on continental margins, which lie at the ocean-atmosphere-earth interface. However, interpretations of these records are challenging, given complex interplays among processes delivering particulate material to and from ocean margins. Here we report radiocarbon $\left({ }^{14} \mathrm{C}\right)$ signatures measured for organic carbon in differing grain-size sediment fractions and foraminifera in a sediment core retrieved from the southwest Iberian margin, spanning the last $\sim 25,000 \mathrm{yr}$. Variable differences of 0-5000 yr in radiocarbon age are apparent between organic carbon in differing grain-sizes and foraminifera of the same sediment layer. The magnitude of ${ }^{14} \mathrm{C}$ differences co-varies with key paleoceanographic indices (e.g., proximal bottom-current density gradients), which we interpret as evidence of Atlantic-Mediterranean seawater exchange influencing grain-size specific carbon accumulation and translocation. These findings underscore an important link between regional hydrodynamics and interpretations of down-core sedimentary proxies.

\footnotetext{
${ }^{1}$ Geological Institute, ETH Zürich, Zürich 8092, Switzerland. ${ }^{2}$ Lyell Centre, Heriot-Watt University, Edinburgh EH14 4AS, United Kingdom. ${ }^{3}$ Laboratory for Ion Beam Physics, ETH Zürich, Zürich 8093, Switzerland. ${ }^{4}$ Department of Earth Sciences, University of Cambridge, Cambridge CB2 3EQ, United Kingdom. ${ }^{5}$ Max Planck Institute for Chemistry, D-55128 Mainz, Germany. ${ }^{6}$ Land Use and Environmental Change Institute, University of Florida, Gainesville, FL 32611 , United States. ${ }^{7}$ Present address: Scottish Universities Environmental Research Centre (SUERC), East Kilbride G750QF, United Kingdom. Correspondence and requests for materials should be addressed to C.R.M. (email: C.Magill@hw.ac.uk)
} 
$\mathrm{P}$ revious studies suggest that dramatic climate changes during glacial terminations, including the last deglaciation, about 23-9 thousand years (kyr) ago, were related to periods of Atlantic meridional overturning circulation slowdown ${ }^{1,2}$. These slowdowns were accompanied by pronounced hydrographic changes ${ }^{3}$ throughout the sub-tropical Atlantic, which are exemplified by paleoceanographic reconstructions off the southwest Iberian margin ${ }^{1,4}$ (Fig. 1). Respective reconstructions demonstrate an antiphase relationship between North Atlantic Deep Water (NADW) formation and the strength of Mediterranean Outflow Water (MOW) during glacial termination ${ }^{5,6}$, which together are important influences on Eurasian and high northlatitude climate conditions ${ }^{7}$.

Microfossils and biogeochemical data suggest that marked paleoceanographic changes occurred in sub-tropical Atlantic circulation at intermediate water depths during glacial termination $^{2,8-12}$, but debate persists about the nature of these changes vis-à-vis apparent disparities among proxies within singular or correlative sediment horizons; ${ }^{13}$ for instance, sea-surface temperatures (SSTs) reconstructed from co-deposited (organic) biomarkers and foraminifera ${ }^{12,14,15}$. There is some evidence suggesting particle re-suspension and lateral translocation (advection) of sediment ${ }^{16}$ within nepheloid layers ${ }^{10,17}$ drive apparent disparities among proxies with differing grain-size associations via sediment (hydrodynamic) sorting processes ${ }^{18-20}$, but this evidence remains inconclusive as sediment mobilization and advection is often stochastic ${ }^{16}$ and difficult to resolve $\mathrm{e}^{21}$.

Here, we reveal the effects of hydrodynamics on carbon accumulation in sediment from southwest Iberian margin coresediments spanning the last $\sim 25 \mathrm{kyr}$ via complementary physicochemical (e.g., grain-size distributions and X-ray fluorescence [XRF]) data and ${ }^{14} \mathrm{C}$ ages measured for organic carbon (OC) in different grain-size classes and foraminifera separated from a 3.44 m-long sediment (Kasten) core recovered in 2013 during cruise JC089 aboard the RSS James Cook in the northeast Atlantic Ocean (Fig. 1). The core site called SHAK06-5K $\left(37.571{ }^{\circ} \mathrm{N}\right.$, $10.153{ }^{\circ} \mathrm{W}, 2646 \mathrm{mbsl}$ ) lies at the lower slope of the southwest Iberian margin, where high sedimentation rates resolve paleoceanographic conditions over decadal-to-orbital timescales ${ }^{4,9}$.

\section{Results and discussion}

Radiocarbon ages of bulk organic carbon and foraminifera. Radiocarbon ages of OC increase with depth in every grain-size class and feature a maximum average radiocarbon age of 20,600 \pm $900 \mathrm{yr}$, when coincident foraminifera reach their maximum calendar age of 21,725 yr BP (Fig. 2). Associated bulk sediment OC ${ }^{14} \mathrm{C}$ feature a consistent down-core difference against foraminifera radiocarbon ages of $1450 \pm 200 \mathrm{yr}$ (Fig. 2) with one exception at $65-66 \mathrm{~cm}$ ( 600 yr offset [Supplementary Data 1]) that fell during prominent Mediterranean sapropel 1 formation ${ }^{22}$ wherein radiocarbon age offsets appear influenced by particularly 'old' foraminifera calendar ages as opposed to unexpectedly young gross sediment TOC. In contrast, the radiocarbon offset between organic carbon in clay-size sediment fractions against foraminifera $\left(R_{\mathrm{C}-\mathrm{F}}\right)$ is more variable, with down-core differences of between about 0-2000 yr (Fig. 3a). The radiocarbon offset between organic carbon in coincident fine or coarse-silts and foraminifera ( $R_{\mathrm{FS}-\mathrm{F}}$ and $R_{\mathrm{CS}-\mathrm{F}}$, respectively) likewise is variable, with down-core differences of $\sim 1000-3500$ yr (Fig. 3a). Because organic carbon in sediment fractions of $>63 \mu \mathrm{m}$ is subject to varied influences of biomineral-bound OC (ref. ${ }^{23}$ ) and incomplete disaggregation of flocculates with effective diameters in excess of $100 \mu \mathrm{m}$ (refs. ${ }^{19,24,25}$ ), we will focus here on changes in down-core radiocarbon offsets apparent between coincident finer sediment fractions and foraminifera. Notwithstanding questions about the reliability of differently preserved tests (translucent versus frosty), prior studies suggest foraminiferal ${ }^{14} \mathrm{C}$ dates are an accurate indication of initial deposition age in rapidly accumulating sediments because of their consistent high settling velocities, whereas co-deposited finer sediments are more subject to (re)suspension with attendant spatio-temporal biases on sedimentary proxies ${ }^{20,26}$.

The organic carbon in all finer sediment fractions (i.e., C, FS and CS) has older radiocarbon ages as compared to coincident foraminifera, and the magnitude of their respective radiocarbon offsets change in step with complementary proxies of (paleo) oceanographic variability since at least $25 \mathrm{kyr}$ ago (Fig. 3; Supplementary Data 1). A lower radiocarbon offset (i.e., decreased $R_{\mathrm{C}-\mathrm{F}}, R_{\mathrm{FS}-\mathrm{F}}$ and $R_{\mathrm{CS}-\mathrm{F}}$ values) during the Last Glacial Maximum (LGM; $23.2 \mathrm{kyr}$ ago) transitions into more moderate offsets of $\sim 2000 \pm 500 \mathrm{yr}$ during preliminary glacial termination, and then rapidly peak to values of $\sim 1500-3500 \mathrm{yr}$ amid the middle of Heinrich Event 1 (HE1; 17.5-14.7 kyr ago). After an interim of lower radiocarbon offset through the conclusion of HE1 and initial Bølling/Allerød interstadial (B/A; 14.7-12.8 kyr ago), the relative age differences among grain-size classes increase again at B/A-to-Younger Dryas (YD; 12.9-11.7 kyr ago) transition with moderate offsets of $\sim 2000 \pm 500$ yr. Low-tointermediate average radiocarbon offsets subsequently persist through the mid-Holocene. Thereafter, respective offsets climb to significantly greater values amid the last few millennia, most likely due to anthropogenic impacts on sedimentary processes ${ }^{27}$ (e.g., particulate material transmission and deposition) ${ }^{28}$.

Potential driver(s) of ${ }^{14} \mathrm{C}$ differences. Previous studies indicate systematic radiocarbon offsets among grain-size classes could be consequent to several different factors ${ }^{29}$, including preferential bioturbation $^{30,31}$, diagenetic alteration or downslope mobilization of foraminiferal tests ${ }^{8}$, and the differential lateral transfer of bottom and intermediate nepheloid layer sediment fractions ${ }^{32}$ via deeper water currents ${ }^{16,20,33}$. However, although benthic organisms can induce age or size-dependent depositional displacement ${ }^{30,31}$, bioturbation effects are unlikely to affect down-core records significantly, given ichnofabric evidence of low-moderate degree $^{34}$ of mid-tier ${ }^{35,36}$ (limited to upper $<10 \mathrm{~cm}$ of the substrate) bioturbation alongside relatively high sedimentation rates ${ }^{31,37}$ and lack of a deep mixed layer ${ }^{29}$ as indicated by ${ }^{210} \mathrm{~Pb}$ from multi-cores at SHAK06-5K (Supplementary Data 3). This evidence is supported by geochemical biodiffusion models ${ }^{38,39}$, which further suggest limited biodiffusive coefficients of $\sim 0.15 \pm$ $0.05 \mathrm{~cm}^{2} \mathrm{yr}^{-1}$ at SHAK06-5K (Supplementary Fig. 4). Diagenetic alteration or downslope remobilization of foraminiferal tests are also unlikely, given coincident foraminifera are consistently younger versus organic carbon and that tests are resistant to winnowing ${ }^{19}$.

There is a moderate correlation apparent between down-core values of $R_{\mathrm{FS}-\mathrm{F}}$ and $R_{\mathrm{CS}-\mathrm{F}}$ and XRF-derived $\mathrm{Zr} / \mathrm{Al}$ ratios of bulk sediment (Fig. 3d-f), which can often serve as a proxy of MOW flow-core velocities ${ }^{40}$, that implies bottom-current flow dynamics are an important factor in controlling grain-size specific resuspension. Yet, the recent MOW flow-core shows an average depth of $\sim 500-1500$ mbsl (ref. ${ }^{41}$ ) that lies well above SHAK06$5 \mathrm{~K}(2646 \mathrm{mbsl})$. Thus, while at least the base of the MOW descended to at least $2600 \mathrm{mbsl}$ (Fig. 1) during past Heinrich events $^{5,41}$, it is improbable that $\mathrm{Zr} / \mathrm{Al}$ trends at SHAK06-5K directly proxy past changes in past MOW flow-core velocities ${ }^{13}$.

Therefore, we compared the differences in normalized $4,40,42$ $\mathrm{Zr} / \mathrm{Al}$ ratios between marine cores recovered from a site close to the Strait of Gibraltar (U1389; $\left.36.425^{\circ} \mathrm{N}, 7.27{ }^{\circ} \mathrm{W}, 644 \mathrm{mbsl}\right)$, which is a sensitive recorder of MOW flow velocities ${ }^{40,42}$, and 
a

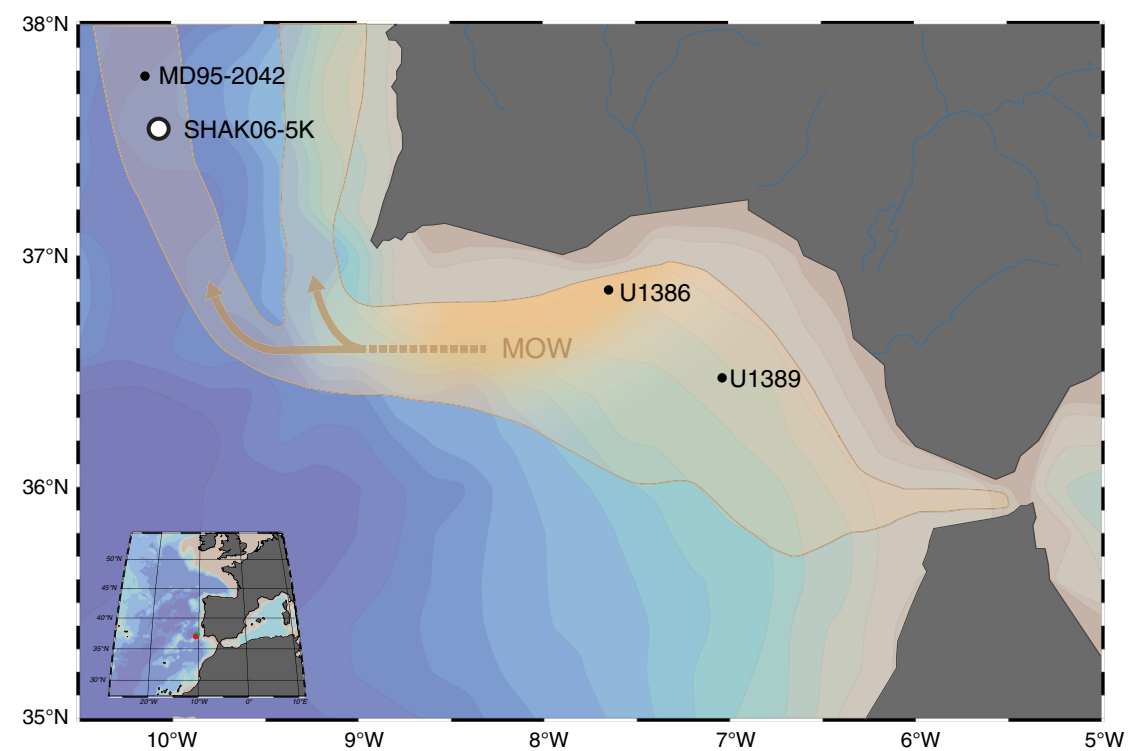

Suspended particulate matter $\left(\mathrm{SPM} \mathrm{mg} \mathrm{m}{ }^{-3}\right.$ )

b

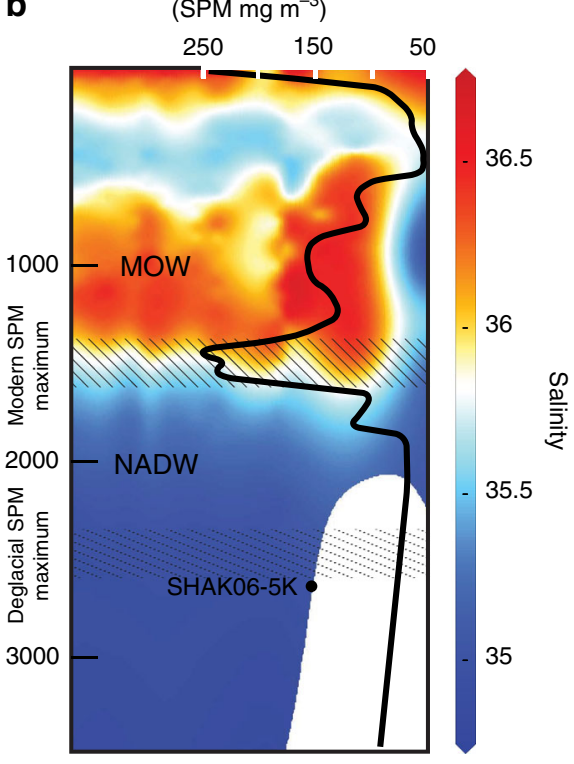

Fig. 1 Core sites and down-column water chemistry profiles. Maps of the southwest lberian margin (a) showing modern ocean current trajectories of Mediterranean outflow water (MOW [shown in orange]), which flows around 500-2000 m depth, and locations of SHAK06-5K (open circle) and MD952042, U1386, and U1389 (black dots). Orange arrows show approximate sediment transfer courses out of the Gulf of Cadiz $9,61,65,84$. Bathymetric contours are shown at $50 \mathrm{~m}$ intervals as adapted from Ocean Data View (Schlitzer, R. Ocean Data View, odv.awi.de, 2018). b, Contemporary profile around $37.5^{\circ} \mathrm{N}$ for salinity, which correlates with seawater density 50 . Also shown are estimates of the modern (solid hatches) and deglacial (stipled hashes) nepheloid layer mixing (peak) depths $16,17,50,84$, which are reflected by particulate-matter concentration maxima. Deglacial nepheloid layer depths are derived from numeric simulations $\mathrm{s}^{50,84}$ considered together with complementary grain-size, isotopic and foraminiferal data regarding glacial MOW dynamics $3,8,50$. NADW, North Atlantic Deep Water

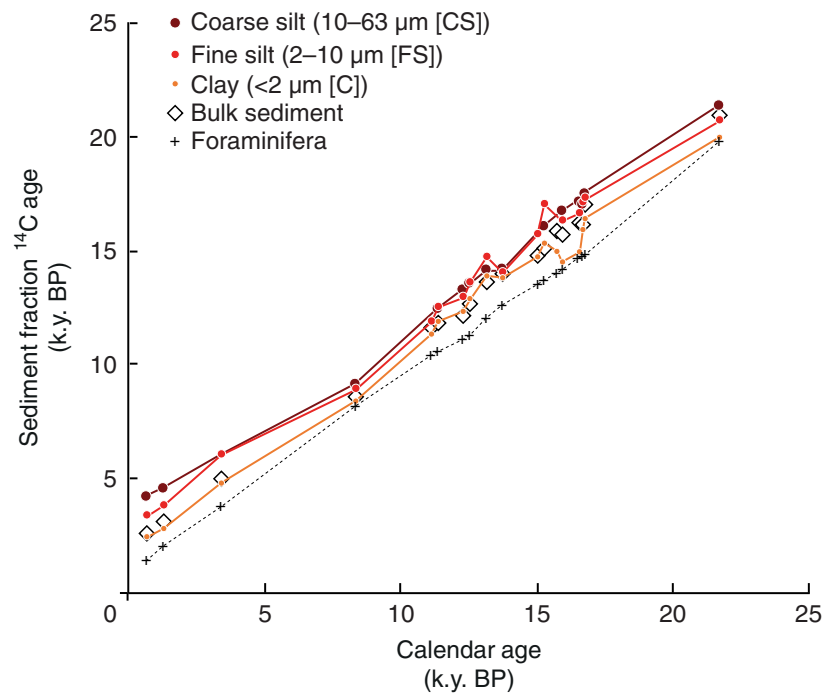

Fig. 2 Down-core age relationships among grain-size sediment fractions. Down-core relationships in conventional ${ }^{14} \mathrm{C}(R)$ age of organic carbon in bulk sediment and among grain-size classes as a function of calendar age derived from ${ }^{14} \mathrm{C}$ measurements on coincident planktonic foraminifera (c.f., Supplementary Data 1). Between sediment-fraction differences are magnified in Fig. 3 and furthermore available in Supplementary Data 1

another site closer to the moat generated by the uppermost MOW (U1386; $36.828{ }^{\circ} \mathrm{N}, 7.755^{\circ} \mathrm{W}, 561 \mathrm{mbsl}$ ), which is sensitive to both MOW flow velocities and flow-core depth ${ }^{42}$. Considered together, such differences should be a robust, though indirect, indicator of MOW flow-core depths ${ }^{42,43}$. Not too surprisingly, patterns of U1389-U1386 differences show a stronger correlation with $R_{\mathrm{FS}-\mathrm{C}}$ and $R_{\mathrm{CS}-\mathrm{C}}$ trends as compared to either core alone (Fig. 3f). With this in mind, here we suggest that $\mathrm{Zr} / \mathrm{Al}$ instead tracks changes in advected finer-grained terrigenous siliclastics entrained in association with a nepheloid layer ${ }^{16,17,44,45}$.

There are significant low-to-moderate strength relationships apparent between radiocarbon offsets and XRF (i.e., manganeseto-aluminum ratio $[\mathrm{Mn} / \mathrm{Al}]$ ) trends at SHAK06-5K (Fig. 3e; Supplementary Data 1) that hint toward the effects of bottom water oxygenation with respect to sediment flux and $\mathrm{OM}$ degradation. Previous studies of Mediterranean seawater and sediment dynamics suggest $\mathrm{Mn} / \mathrm{Al}$ trends in regional deep-sea sediments correlate with redox conditions ${ }^{22}$ that, in turn, impact the abundance and degradation (e.g., 'pre-aged') of $\mathrm{OM}$ in sediments and suspended particulate matter (SPM) through cyclic oxygen (re)exposure ${ }^{46,47}$. More specifically, paleoceanographic reconstructions of deglacial MOW fluctuations suggest that there was increased discharge of deep-and-intermediate waters ${ }^{48}$ with high amounts of fine sediment fractions and $\mathrm{TOC}^{22,49}$.

Insomuch as nepheloid layer dynamics and bottom current flow velocities along the Iberian margin are each related to seawater density gradients ${ }^{44}$ between regional MOW and Atlantic seawater ${ }^{41,50}$, increased $\mathrm{Zr} / \mathrm{Al}$ and $\mathrm{Mn} / \mathrm{Al}$ ratios most likely parallel the enhanced lateral transport flux and deposition of finer sediments (i.e., silts) as compared to vertical input of fresh hemipelagic materials ${ }^{22,48}$ because of the deeper, enhanced nepheloid layer developed between seawater masses with disparate densities ${ }^{16,17}$. This interpretation is consistent with the nominal differences in down-core sortable silt distributions (Supplementary Data 1) and is reinforced by parallel down-core records of the unsupported ${ }^{231} \mathrm{~Pa}$-to-230 Th ratios at SU81-18 

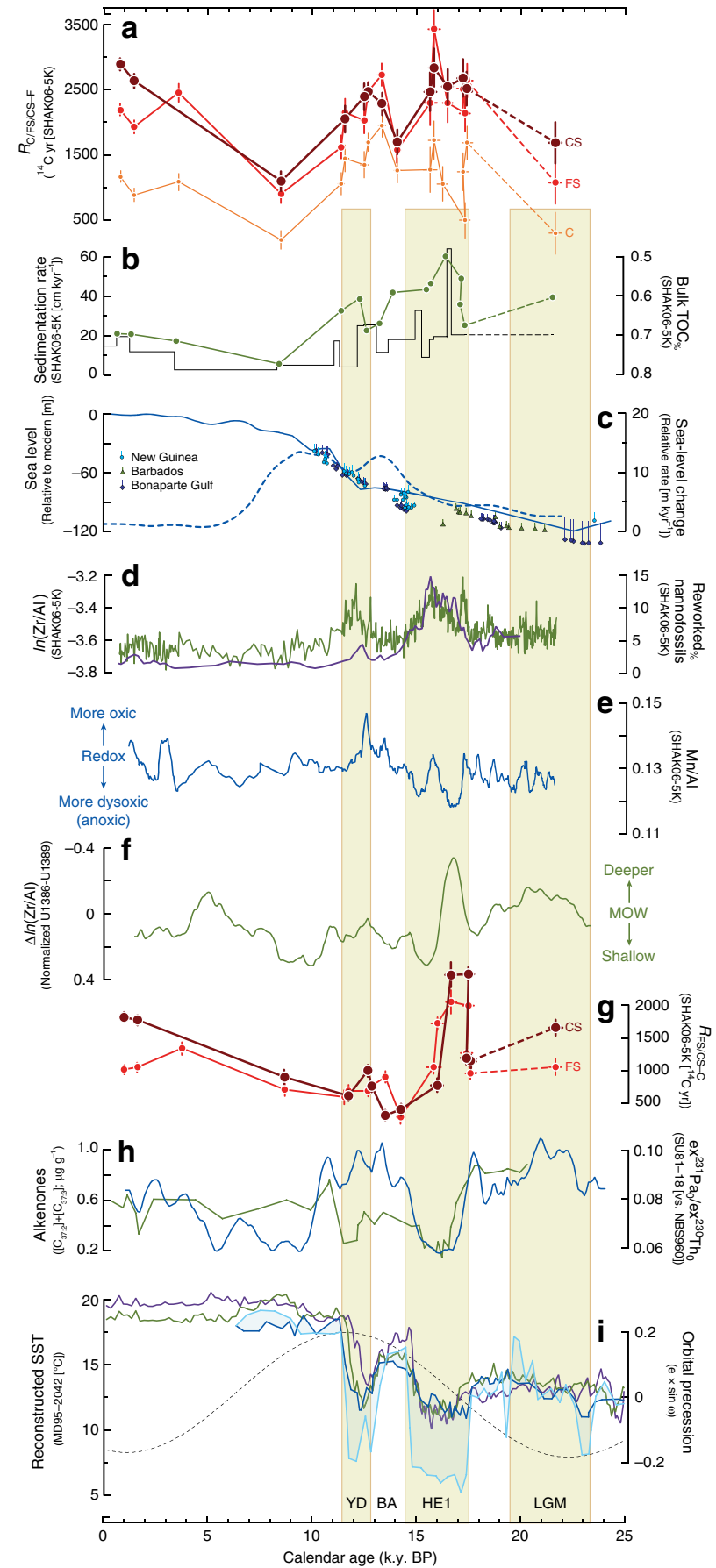

$\left(37.767{ }^{\circ} \mathrm{N}, 10.183^{\circ} \mathrm{W}, 3135 \mathrm{mbsl}\right)$ (Fig. $\left.3 \mathrm{~h}\right)$. Thus, we suggest that it is not MOW flow-core velocity, in itself, that drives apparent $\mathrm{Zr} / \mathrm{Al}$ trends at SHAK06-5K, but the associated nepheloid layer(s) that develops alongside wider salinity gradients amid Atlantic-Mediterranean seawater masses ${ }^{17,44}$ at lower depths $s^{50}$. This association squares with observations of turbulent (re)suspension of finer sediment from upper slopes at their contact with uppermost MOW flow (c.f., internal tides) ${ }^{16,51}$ that then settles at MOW-NADW interface ${ }^{16,17,22,52}$ along with SPM transported from up-current distal locations $9,16,22,48$. Aforementioned drivers also square with the moderate correlation strength between radiocarbon offsets and down-core sedimentation rate (Fig. 3a, b) and inferred benthic redox conditions (Fig. 3e), both of which are entwined to changes in sea-level ${ }^{22}$. This combination
Fig. 3 Deglacial trends in down-core records at SHAK06-5K and vicinal Iberian Margin ocean cores. Comparison of down-core sedimentary proxies at Iberian margin sites during glacial termination and Holocene.

a Radiocarbon age offset between grain-size sediment fractions (clay $[\mathrm{C}]$, fine silt $[\mathrm{FS}]$, coarse silt $[\mathrm{CS}]$, foraminifera $[\mathrm{F}] ; R_{x-y}=R_{x}-R_{y}$, where $x$ and $y$ represent discrete sediment fractions [c.f., eq. 1]) isolated from the same sediment core intervals of SHAK06-5K. Also shown are propagated $1 \sigma$ (s. d.) uncertainties of differences in radiocarbon age among grain-size sediment fractions (c.f., Supplementary Data 1). b Average sedimentation rates of the sediments at SHAK06-5K (black line [c.f., Supplementary

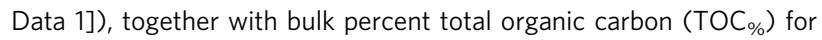
respective sediments (N.B., the axis reversal for improved down-core comparisons). c Relative sea-level (RSL) fluctuations of the southeast Portuguese margin 27,28 (blue solid line) beside corresponding global RSL data with depth uncertainties ${ }^{85}$. The rate of sea-level change is also shown, as modeled in Monte Carlo experiments with $6 \mathrm{~m}$ coral depth uncertainty ${ }^{86}$. d Zirconium-to-Aluminum ( $\mathrm{Zr} / \mathrm{Al}$ ) ratios of bulk sediments at SHAK06-5K (green solid line). Raw values are natural-log transformed to improve data normality. Also shown are relative abundance (percentage) of reworked nannofossils in down-core sediments at SHAK06-5K (c.f.,

Supplementary Data 4). e Manganese-to Aluminum ( $\mathrm{Mn} / \mathrm{Al}$ ) ratios of bulk sediments at SHAK06-5K, which serve as a relative indicator of benthic redox conditions ${ }^{22}$. $\mathbf{f}$ Difference between normalized $\mathrm{Zr} / \mathrm{Al}$ ratios at $\mathrm{U} 1386$ and U1389 (ref. ${ }^{40}$ ) that theoretically presents a surrogate measure of MOW flow depth ${ }^{43}$. R Radiocarbon age offset between co-occurring grainsize classes as compared to clays at SHAK06-5K. Again, corresponding propagated $1 \sigma$ uncertainties of differences in radiocarbon age among grainsize sediment fractions are also shown (c.f., Supplementary Data 1). g Alkenone concentrations ( $C_{37: 2}+C_{37: 3}$ [light blue solid line]) for at MD95-2042 (ref. ${ }^{14}$ ); higher values indicate increasing primary production or increases in organic matter preservation ${ }^{55}$. Also shown is excess ${ }^{231} \mathrm{~Pa}$ to-230 Th ratio at SU18-81 (green solid line), demonstrative of bottom-water circulation strength ${ }^{2}$. h Parallel down-core reconstructions of sea-surface temperature at MD95-2042 derived from coincident foraminifera assemblages $^{67}$ (purple solid line), alkenones (light blue ${ }^{67}$ and dark blue ${ }^{14}$ solid lines, respectively) and tetraethers ${ }^{14}$ (green solid line). Also shown is calculated orbital precession (dashed black line), which equals the product of calculated eccentricity (e) and the sine function of longitude of the perihelion $(\omega)$. Dashed lines connecting points represent intervals of low data resolution and high meltwater release, which could drive anomalous radiocarbon values ${ }^{1,83}$. BA Bølling/Allerød, HE1 Heinrich Event 1, LGM Last Glacial Maximum, YD Younger Dryas

of (hydro)physical drivers would drive increased injection of turbid Mediterranean water masses into the Gulf of Cadiz at high velocities during periods of deglacial transgression $6,48,49$, alongside regional increases in rainfall (i.e. river discharge) and benthic dysoxia $^{22,48,49}$. As such, times of stronger MOW flow would thus result in more advection of fine grained terrigenous clastic material to our site, which then would be admixed together with local hemipelagic rain in varying proportions ${ }^{18,49,53}$.

Although the exact balance of MOW temperature-salinity parameters during glacial termination remains uncertain ${ }^{41,54}$, reconstructed densities $(\sigma)$ of important Atlantic-Mediterranean seawater masses are more certain. The contrast between reconstructed densities of MOW and NADW through Greenland stadials $\left(\sigma_{\mathrm{MOW}}-\sigma_{\mathrm{NADW}}=2.4 \mathrm{~kg} \mathrm{~m}^{-3}\right)$ is much larger as compared to warmer (interstadial) intervals $\mathrm{s}^{41}$, such as the recent Holocene $^{45,54}\left(\sigma_{\mathrm{MOW}}-\sigma_{\mathrm{NADW}}=0.7 \mathrm{~kg} \mathrm{~m}^{-3}\right)$. Considered together with evidence of low-moderate degree ${ }^{34}$ of mid-tier $(<$ $10 \mathrm{~cm}$ of the substrate) bioturbation ${ }^{35,36}$, our data suggest that down-core radiocarbon age offsets among grain-size classes are consequent - at least in part - to differential hydrodynamic 
effects on sediment lateral transfer vis-à-vis differences in regional Atlantic-Mediterranean seawater densities and flow depths. All data considered together, we suggest there are competing influences of (hemi)pelagic dilution vs. advection of finer sediment fractions as a function of MOW depth and OM degradation extent that, in turn, are related to regional (Mediterranean) terrestrial hydroclimate, ocean circulation dynamics, and benthic oxygenation.

(Paleo)oceanographic implications. Considerable changes occurred in regional MOW dynamics (i.e., current depth and flow velocities) during glacial termination ${ }^{9,40,42,43}$, about $20-10 \mathrm{kyr}$ ago; however, important details of these changes remain unclear. Increasing grain-sizes ${ }^{42}$ and increases in reworked nannofossil influx $^{11,55}$ (Fig. 3d) during deglacial transitions and the midHolocene correspond to intervals of decreased Nile river discharge ${ }^{56}$, which led to more saline (denser) MOW ${ }^{41,45,50}$, and decreased formation of less dense, cold NADW ${ }^{54,57}$. Intervals associated with cold Arctic conditions $2,54,56$ show decreased percent total OC (TOC\% [Fig. 3b]) together with overall high sedimentation rates (Supplementary Data 1), which typically parallel OC burial efficiency ${ }^{37}$. Although relative differences in terrestrial input (vs. marine) could be one explanation of these observations, it does not befit the consistent low ratio values of bulk carbon-to-nitrogen (Supplementary Data 1) and branched isoprenoid tetraethers ${ }^{14}$ (BIT) that together indicate negligible soil OM input throughout the last $25 \mathrm{kyr}$. Decreased TOC\% through these intervals also does not track the significant, though varied, disparities in relative abundances or reconstructed temperatures among principle oceanography proxies $^{14}$ (i.e., alkenones, isoprenoid tetraethers, and foraminifera [Fig. 3h, i]).

One approach to reconcile such apparent discrepancies invokes recent data suggesting grain-sizes of 10-63 $\mu \mathrm{m}$ (c.f., CS) feature especially protracted lateral transport histories in ocean margin systems ${ }^{33,58,59}$, such that CS fractions contain decreasing proportions of fresh organic matter and decreased TOC $\%$ through time via progressive pre-depositional degradation ${ }^{23,33}$. During progressive oxic degradation, residual OC in CS fractions will become increasingly pre-aged because of decreased fresh organic matter and its accumulative residence in nepheloid layers over repeated (re)suspension-deposition cycles ${ }^{21,33,58-60}$.

Interestingly, previous studies reveal that the recent MOW transfers particulate matter with an average diameter of 5-25 $\mu \mathrm{m}$ (refs. ${ }^{17,61}$ ) from coastal Atlantic sources (Gulf of Cádiz) ${ }^{55,61}$ that then is entrained to more distal locations of the continental Iberian margin. Assuming grain-sizes of $2-10 \mu \mathrm{m}$ (c.f., FS) have similar sediment transport histories as coarser silt ${ }^{51,59}$, these combined data suggest that $R_{\mathrm{FS}-\mathrm{C}}$ and $R_{\mathrm{CS}-\mathrm{C}}$ trends (Fig. $3 \mathrm{~g}$ ) are related to relative differences in organic carbon mixing proportions and degradation among grain-size classes as controlled by pre-depositional translocation (entrainment) time, although the specific mechanisms responsible for apparent bulk ${ }^{14} \mathrm{C}$ differences remain speculative in lieu of biomarker compositional data in corresponding grain-size sediment fractions.

Our analyses reveal down-core coherence of $\mathrm{TOC}_{\%}$ and the corresponding proportion of OC derived from clay $(r=0.789$ [Supplementary Data 1]) that drive strong parallels of $\mathrm{TOC}_{\%}$ against $R_{\mathrm{CS}-\mathrm{C}}$ and $R_{\mathrm{FS}-\mathrm{C}}$ (Fig. $3 \mathrm{~b}, \mathrm{~g}$ ). In contrast, TOC $\%$ has weak correlations with both fine- and the coarse silt fractions (Supplementary Data 1). As such, marked decreases of TOC\% during parts of HE1 and YD (Fig. 3b) follow alongside a relative shift towards more refractory, pre-aged OC in coarse and fine-silt fractions (Fig. 3g, Supplementary Data 1) independent of OC dilution or isotopic mass balance. Assuming particle entrainment during deglacial formation of MOW-related nepheloid layers was also dominated by grain-sizes of $15 \pm 10 \mu \mathrm{m}$ (ref. ${ }^{17}$ ), these data suggest there was increased lateral (re)suspension of finer sediment ${ }^{19,52,59,62}$ (i.e., silt) with relatively pre-aged $\mathrm{OC}^{21,33,58}$ derived from more remote allochthonous sources ${ }^{63}$ such as marginal Gulf of Cadiz drift deposits ${ }^{61,64,65}$.

Apparent discrepancies among (paleo)oceanography proxies. Differential lateral transfer dynamics among grain-size classes may help to explain apparent disparities among proxies during paleoceanographic reconstructions in drift deposits when a single age-depth model is adopted for all down-core records (c.f., Fig. 3i). For example, earlier studies reveal disparities in seasurface temperature (SST) estimates reconstructed from alkenones $^{14,55}$, glycerol dialkyl glycerol tetraethers ${ }^{14,66}$ (GDGTs), and foraminifera $12,15,67$ from correlative down-core records at MD952042 (ref. ${ }^{14}$ ). Although some of these disparities could be consequent to multiple or independent factors ${ }^{14,66}$ (e.g., phylogenetic or other species-dependent factors), degradation and hydrodynamic effects could have an intrinsic role in explaining such proxy paradoxes ${ }^{13,59,63,68}$.

Overall MOW flow velocities decline from $>250 \mathrm{~cm} \mathrm{~s}^{-1}$ at the strait of Gibraltar to about $10-15 \mathrm{~cm} \mathrm{~s}^{-1}$ off Cape St. Vicente spur and $<10 \mathrm{~cm} \mathrm{~s}^{-1}$ along the western Portuguese slope ${ }^{65}$. Considered together with observations that demonstrate resuspension of fine silts and benthic aggregates occurs when respective currents exceed 15 -to- $25 \mathrm{~cm} \mathrm{~s}^{-1}$ (refs. 19,59,62), this suggests a critical threshold for deceleration is crossed in the vicinity of SHAK06-5K that might lead to differential degradation $^{24,29,33,58}$ and deposition of advected SPM from up-current locations ${ }^{65}$. Accepting previous studies showing prototypic organic matter aggregates and fine surface-sediments of the southwest Portuguese margin show average settling speeds of $\sim 0.015 \mathrm{~cm} \mathrm{~s}^{-1}$ within associated MOW branches and spend $\sim 50 \%$ of time in (re)suspension ${ }^{52,59}$, these combined data insinuate advective displacement distances of up to several hundreds of kilometres (c.f., Alboran $\mathrm{Sea}^{25}$ ) that befit the results of bottom boundary (BOBO) landers ${ }^{53}$ and bottom-current circulation simulations ${ }^{65}$.

Alkenones and GDGTs show dissimilar radiocarbon age offsets $^{26,69,70}$ as compared to coincident foraminifera in north Atlantic drift deposits ${ }^{20}$ that befit the combination of their differing grain-size associations ${ }^{31,59}$ and degradation recalcitrance $29,68,70$. Previous studies indicate alkenones, which are more recalcitrant to oxidation ${ }^{20,26,70}$, occur in association with sedimentary particles of $<6 \mu \mathrm{m}$ (refs. ${ }^{71,72}$ ), but less-recalcitrant GDGTs ${ }^{66,69}$ are associated with sedimentary particles of $6-32 \mu \mathrm{m}$ (ref. ${ }^{73}$ ). Although sorting processes are subject to variable and differential influences among grain-sizes (e.g., particle sphericity, particle aggregation, and turbidity [particle concentration] $)^{59,60}$ and between sedimentary particles of the same size (e.g., grain mineralogy [illite vs. kaolinite] $)^{74}$, analogous molecular sedimentfraction associations ${ }^{23,29}$ - and thus relative age offsets ${ }^{25,33,45,64}$ are also implied for southwest Portuguese margin sites ${ }^{71}$, wherein down-core alkenone and GDGT-derived SST trends are offset (lagged), like $R_{\mathrm{CS}-\mathrm{FS}}$ values, about $200 \mathrm{yr}$ on average, and likewise are offset from coincident foraminifera-derived SSTs up to several hundreds of years (Fig. 3g, i).

The magnitude of time offset between organic sedimentary proxies of SST through deglaciation is consistent with the average radiocarbon age offsets of their corresponding grain-size classes (i.e., alkenones $[\mathrm{FS}]$ and GDGTs [CS]) (Fig. 3a, i). Stepwise increases in instantaneous (differential) lag phase amid HE1 and YD happen in concert with high radiocarbon offsets (Supplementary Fig. 3), high MOW flow velocities and densities (Fig. $3 \mathrm{~d}-\mathrm{f}$ ), and elevated fluxes of reworked nannofossils ${ }^{11,55}$ 
(Fig. 3d) despite rather uniform ${ }^{4,45}$ corresponding grain-size distributions at SHAK06-5K (Supplementary Data 1). Like some other studies ${ }^{13,59}$, these same increases do not feature changes in median diameter of the sortable silts (equivalent to coarse silt [CS] fraction), which are often used to reconstruct flow velocities ${ }^{9}$. Further work, especially paired ${ }^{14} \mathrm{C}$ measurements of differing proxies (e.g., alkenones) and their carrier phase (e.g., coccolithophores), is essential to establish the occurrence and significance of these phenomena. Even so, our study provides support for significant hydrodynamic effects on organic carbon transport, degradation, and deposition on ocean margins, and interpretations of related (paleo)climate records.

To summarize, organic radiocarbon age differences among grain-size classes as compared to coincident foraminiferal tests in marine sediments of the northeast Atlantic margin reveal differential lateral transfer dynamics accompanying particle mobilization, as controlled by paleo-current densities vis-à-vis nepheloid layer dynamics. Intervals with intensified Mediterranean Outflow, which closely parallel increased AtlanticMediterranean seawater density contrasts, amid Heinrich Event 1 have much higher radiocarbon offsets among grain-size classes of $\sim 1000-2500 \mathrm{yr}$ and lower organic carbon concentrations as compared to intervals with more sluggish Mediterranean Outflow amid the mid-Holocene. In consequence, our results suggest differential lateral transfer dynamics can influence apparent lead-lag patterns among proxies with differing grain-size associations; as such, hydrodynamic influences on organic carbon accumulation and transfer are important factors to consider in interpretations of diverse co-occurring proxies in down-core records, which can experience differential degradation and hydrodynamic (sorting) processes.

\section{Methods}

Sediment sampling procedures and fraction separation. The entire core was sectioned at $1-\mathrm{cm}$ resolution on-board, from which 21 discrete sediment intervals $(\sim 50 \mathrm{~g})$ were sub-sampled, before storage at $-20^{\circ} \mathrm{C}$. Sub-samples were separated through wetted fine-mesh sieves ${ }^{75}$ and tube settling protocol ${ }^{76}$ to create a series of four grain-size sediment fractions: clay $(<2 \mu \mathrm{m}[\mathrm{C}])$, fine silt $(2-10 \mu \mathrm{m}$ [FS]), coarse silt $(10-63 \mu \mathrm{m}[\mathrm{CS}])$, and sand $(>63 \mu \mathrm{m}[\mathrm{S}])$. Although sediment-fraction recoveries were not monitored directly, previous studies demonstrate wet-sieve recovery percentages exceed $85 \%$ both for mass and bulk organic carbon in most instances ${ }^{60}$ and have a nominal influence on associated bulk sediment-fraction isotopic signatures ${ }^{71,77}$ despite small, though significant, losses of dissolved organic matter during rinsing. Likewise, measured total bulk organic compositions correlate with mass-balance calculations of the organic composition among grain-size sediment fractions ( $r^{2}=0.718$ [c.f., Supplementary Data 1 and Supplementary Fig. 2]). Wellpreserved tests of the planktonic foraminifer Globigerina bulloides-abbreviated "F" for foraminifera-were subsequently picked from associated 200-250 $\mu \mathrm{m}$ sediment fractions.

Sample analysis. Radiocarbon measurements of foraminiferal tests and decarbonated (hydrochloric acid fumigated $)^{78}$ bulk sediment fractions were made on a mini-carbon dating system 79 (MICADAS) following graphitization or via elemental analyser as detailed previously ${ }^{80}$. Radioactive carbon isotope compositions are shown as conventional ${ }^{14} \mathrm{C}$ ages $(R \pm 1 \sigma$ s.d. $)$ to calculate relative age relationships (i.e., offsets) ${ }^{81}$ among grain-size classes, where $x$ and $y$ represent discrete sediment fractions:

$$
R_{x-y}=R_{x}-R_{y}
$$

To calculate absolute age relationships ${ }^{26,33}$, however, conventional ${ }^{14} \mathrm{C}$ ages of foraminiferal tests were converted into calendar years in an age-depth model (CALIB 7.1) ${ }^{82}$ with a dynamic marine inorganic carbon reservoir correction (Supplementary Data 1) that is consistent with chronostratigraphic constraints imposed by planktonic oxygen isotope records ${ }^{1,2,83}$ from MD95-2042/MD99$2334 \mathrm{~K}\left(37.799^{\circ} \mathrm{N}, 10.168^{\circ} \mathrm{W}, 3146 \mathrm{mbsl}\right)$ to within several hundred years ${ }^{83}$. XRF (Avaatech [University of Cambridge]) analyses were used for semi-quantitative analysis at $0.5 \mathrm{~cm}$ depth intervals on u-channel (sub)cores extracted from composite split-core scans of SHAK06-5K Kasten core material (c.f., Supplementary Data 2).
Age models. Foraminiferal (Globigerina bulloides) test ${ }^{14} \mathrm{C}$ ages were used to construct the age model for SHAK06-5K $\left(37.571^{\circ} \mathrm{N}, 10.153^{\circ} \mathrm{W}, 2646 \mathrm{mbsl}\right)$. To do so, surface reservoir ages estimated from at MD99-2334K $\left(37.799^{\circ} \mathrm{N}, 10.168{ }^{\circ} \mathrm{W}\right.$, $3146 \mathrm{mbsl})^{1}$ were subtracted from each conventional ${ }^{14} \mathrm{C}$ date (c.f., Supplementary Data 1) before conversion to calendar ages with CALIB 7.1 (ref. ${ }^{82}$ ). Then, respective calendar ages were used to construct down-core sediment depth-age models after stratigraphic alignment (c.f., Supplementary Fig. 1) against U1385 $\left(37.571^{\circ} \mathrm{N}, 10.126^{\circ}\right.$ $\mathrm{W}, 2578 \mathrm{mbsl})^{4}$. With this in mind, the corresponding propagated $1 \sigma$ uncertainties used for estimating phase relationships fall below about $150 \mathrm{yr}$ with few exceptions (c.f., Supplementary Data 1). We note that these uncertainties do not have much influence on our interpretations of lead/lag phase among proxy records (c.f., Fig. 3g, i) because appertaining proxies (i.e, $R_{\mathrm{CFS} / \mathrm{CS}-\mathrm{C}}$ and tetraether/alkenone-derived SST) are derived from singular cores (SHAK06-5K and MD95-2042, respectively) and thus are internally consistent.

\section{Data availability}

The authors declare all the new data used to support this research are available within the article and its supplementary information files.

Received: 27 October 2017 Accepted: 19 September 2018

Published online: 08 November 2018

\section{References}

1. Skinner, L. C., Waelbroeck, C., Scrivner, A. E. \& Fallon, S. J. Radiocarbon evidence for alternating northern and southern sources of ventilation of the deep Atlantic carbon pool during the last deglaciation. Proc. Natl Acad. Sci. USA 111, 5480-5484 (2014).

2. Gherardi, J. M. et al. Evidence from the Northeastern Atlantic basin for variability in the rate of the meridional overturning circulation through the last deglaciation. Earth Planet. Sc. Lett. 240, 710-723 (2005).

3. Voelker, A. H. L. \& de Abreu, L. in Abrupt Climate Change: Mechanisms, Patterns, and Impacts (eds H. Rashid, L. Polyak, \& E. Mosley-Thompson) 15-37 (American Geophysical Union, 2011).

4. Hodell, D. et al. A reference time scale for Site U1385 (Shackleton Site) on the SW Iberian Margin. Glob. Planet. Change 133, 49-64 (2015).

5. Rogerson, M., Rohling, E. J. \& Weaver, P. P. Promotion of meridional overturning by Mediterranean-derived salt during the last deglaciation. Paleoceanography 21, PA4101 (2006).

6. Voelker, A. H. L. et al. Mediterranean outflow strengthening during northern hemisphere coolings: a salt source for the glacial Atlantic? Earth Planet. Sc. Lett. 245, 39-55 (2006).

7. Ivanovic, R. F., Valdes, P. J., Gregoire, L., Flecker, R. \& Gutjahr, M. Sensitivity of modern climate to the presence, strength and salinity of MediterraneanAtlantic exchange in a global general circulation model. Clim. Dynam. 42, 859-877 (2014)

8. Schönfeld, J. \& Zahn, R. Late Glacial to Holocene history of the Mediterranean Outflow: evidence from benthic foraminiferal assemblages and stable isotopes at the Portuguese margin. Palaeogeogr. Palaeocl. 159, 85-111 (2000).

9. Toucanne, S. et al. Contourites of the Gulf of Cadiz: a high-resolution record of the paleocirculation of the Mediterranean outflow water during the last 50,000 years. Palaeogeogr. Palaeocl. 246, 354-366 (2007).

10. Stumpf, R., Frank, M., Schönfeld, J. \& Haley, B. A. Climatically driven changes in sediment supply on the SW Iberian shelf since the Last Glacial Maximum. Earth Planet. Sc. Lett. 312, 80-90 (2011).

11. Palumbo, E. et al. Abrupt variability of the last 24 ka BP recorded by coccolithophore assemblages off the Iberian Margin (core MD03-2699). J. Quat. Sci. 28, 320-328 (2013).

12. Salgueiro, E. et al. Past circulation along the western Iberian margin: a time slice vision from the Last Glacial to the Holocene. Quat. Sci. Rev. 106, 316-329 (2014).

13. Mulder, T. et al. Contourites in the Gulf of Cadiz: a cautionary note on potentially ambiguous indicators of bottom current velocity. Geo. -Mar. Lett. 33, 357-367 (2013).

14. Darfeuil, S. et al. Sea surface temperature reconstructions over the last $70 \mathrm{kyr}$ off Portugal: biomarker data and regional modeling. Paleoceanography 31, 40-65 (2016).

15. Cayre, O., Lancelot, Y., Vincent, E. \& Hall, M. A. Paleoceanographic reconstructions from planktonic foraminifera off the Iberian Margin: temperature, salinity, and Heinrich events. Paleoceanography 14, 384-396 (1999).

16. Quaresma, L. S., Vitorino, J., Oliveira, A. \& da Silva, J. Evidence of sediment resuspension by nonlinear internal waves on the western Portuguese midshelf. Mar. Geol. 246, 123-143 (2007). 
17. Oliveira, A. et al. Nepheloid layer dynamics in the northern Portuguese shelf. Prog. Oceanogr. 52, 195-213 (2002).

18. Lebreiro, S. M. et al. Sediment instability on the Portuguese continental margin under abrupt glacial climate changes (last 60kyr). Quat. Sci. Rev. 28, 3211-3223 (2009).

19. Thomsen, L. \& Gust, G. Sediment erosion thresholds and characteristics of resuspended aggregates on the western European continental margin. DeepSea Res. Pt. I 47, 1881-1897 (2000).

20. Ohkouchi, N., Eglinton, T. I., Keigwin, L. D. \& Hayes, J. M. Spatial and temporal offsets between proxy records in a sediment drift. Science 298, 1224-1227 (2002).

21. Tesi, T. et al. Reexposure and advection of ${ }^{14} \mathrm{C}$-depleted organic carbon from old deposits at the upper continental slope. Global Biogeochem. Cy. 24 10.1029/2009GB003745 (2010)

22. Rogerson, M. et al. A dynamic explanation for the origin of the western Mediterranean organic-rich layers. Geochem. Geophys. Geosy. 9, Q0740 (2008).

23. Arnarson, T. S. \& Keil, R. G. Changes in organic matter-mineral interactions for marine sediments with varying oxygen exposure times. Geochim. Cosmochim. Ac. 71, 3545-3556 (2007).

24. García, R. et al. Sediment bioavailable organic matter, deposition rates and mixing intensity in the Setúbal-Lisbon canyon and adjacent slope (Western Iberian Margin). Deep-Sea Res. Pt. I 57, 1012-1026 (2010).

25. Pando, S., Juliano, M., García, R., de Jesus Mendes, P. \& Thomsen, L. Application of a lagrangian transport model to organo-mineral aggregates within the Nazaré canyon. Biogeosciences 10, 4103 (2013).

26. Mollenhauer, G. et al. An evaluation of ${ }^{14} \mathrm{C}$ age relationships between cooccurring foraminifera, alkenones, and total organic carbon in continental margin sediments. Paleoceanography 20, PA1016 (2005).

27. Dias, J., Boski, T., Rodrigues, A. \& Magalhães, F. Coast line evolution in Portugal since the Last Glacial Maximum until present-a synthesis. Mar. Geol. 170, 177-186 (2000).

28. Delgado, J. et al. Sea-level rise and anthropogenic activities recorded in the late Pleistocene/Holocene sedimentary infill of the Guadiana Estuary (SW Iberia). Quat. Sci. Rev. 33, 121-141 (2012).

29. Zonneveld, K. A. F. et al. Selective preservation of organic matter in marine environments; processes and impact on the sedimentary record. Biogeosciences 7, 483-511 (2010).

30. Smith, C. R., Pope, R. H., DeMaster, D. J. \& Magaard, L. Age-dependent mixing of deep-sea sediments. Geochim. Cosmochim. Ac. 57, 1473-1488 (1993).

31. Bard, E. Paleoceanographic implications of the difference in deep-sea sediment mixing between large and fine particles. Paleoceanography 16, 235-239 (2001).

32. Karakaş, G. et al. High-resolution modeling of sediment erosion and particle transport across the northwest African shelf. J. Geophys. Res. 111, C06025 (2006).

33. Mollenhauer, G. et al. Aging of marine organic matter during cross-shelf lateral transport in the Benguela upwelling system revealed by compoundspecific radiocarbon dating. Geochem. Geophys. Geosy. 8, Q09004 (2007).

34. Dorador, J. \& Rodríguez-Tovar, F. J. Stratigraphic variation in ichnofabrics at the "Shackleton Site" (IODP Site U1385) on the Iberian Margin: paleoenvironmental implications. Mar. Geol. 377, 118-126 (2016).

35. Baas, J., Schönfeld, J. \& Zahn, R. Mid-depth oxygen drawdown during Heinrich events: evidence from benthic foraminiferal community structure, trace-fossil tiering, and benthic $\delta^{13} \mathrm{C}$ at the Portuguese Margin. Mar. Geol. 152, 25-55 (1998).

36. Baas, J. H., Mienert, J., Abrantes, F. \& Prins, M. A. Late Quaternary sedimentation on the Portuguese continental margin: climate-related processes and products. Palaeogeogr. Palaeoclimatol. Palaeoecol. 130, 1-23 (1997).

37. Masson, D. G. et al. Efficient burial of carbon in a submarine canyon. Geology 38, 831-834 (2010)

38. Nittrouer, C., DeMaster, D., McKee, B., Cutshall, N. \& Larsen, I. The effect of sediment mixing on $\mathrm{Pb}-210$ accumulation rates for the Washington continental shelf. Mar. Geol. 54, 201-221 (1984).

39. Meysman, F. J., Boudreau, B. P. \& Middelburg, J. J. Relations between local, nonlocal, discrete and continuous models of bioturbation. J. Mar. Res. 61, 391-410 (2003).

40. Bahr, A. et al. Persistent monsoonal forcing of Mediterranean Outflow Water dynamics during the late Pleistocene. Geology 43, 951-954 (2015).

41. Rogerson, M. et al. Enhanced Mediterranean-Atlantic exchange during Atlantic freshening phases. Geochem. Geophys. Geosy. 11, Q08013 (2010).

42. Bahr, A. et al. Deciphering bottom current velocity and paleoclimate signals from contourite deposits in the Gulf of Cádiz during the last $140 \mathrm{kyr}$ : an inorganic geochemical approach. Geochem. Geophys. Geosy. 15, 3145-3160 (2014).
43. Kaboth, S., Bahr, A., Reichart, G.-J., Jacobs, B. \& Lourens, L. J. New insights into upper MOW variability over the last $150 \mathrm{kyr}$ from IODP 339 Site U1386 in the Gulf of Cadiz. Mar. Geol. 377, 136-145 (2016).

44. Puig, P., Palanques, A., Guillén, J. \& El Khatab, M. Role of internal waves in the generation of nepheloid layers on the northwestern Alboran slope: implications for continental margin shaping. J. Geophys. Res. 109, C09011 (2004).

45. Hanebuth, T. J., Zhang, W., Hofmann, A. L., Löwemark, L. A. \& Schwenk, T. Oceanic density fronts steering bottom-current induced sedimentation deduced from a 50 ka contourite-drift record and numerical modeling (off NW Spain). Quat. Sci. Rev. 112, 207-225 (2015).

46. Blair, N. E. \& Aller, R. C. The fate of terrestrial organic carbon in the marine environment. Annu. Rev. Mar. Sci. 4, 401-423 (2012).

47. Hedges, J. I. et al. Sedimentary organic matter preservation; a test for selective degradation under oxic conditions. Am. J. Sci. 299, 529-555 (1999).

48. Jiménez-Espejo, F. J. et al. Geochemical evidence for intermediate water circulation in the westernmost Mediterranean over the last $20 \mathrm{kyrBP}$ and its impact on the Mediterranean Outflow. Glob. Planet. Change 135, 38-46 (2015).

49. Martinez-Ruiz, F. et al. Paleoclimate and paleoceanography over the past $20,000 \mathrm{yr}$ in the Mediterranean Sea Basins as indicated by sediment elemental proxies. Quat. Sci. Rev. 107, 25-46 (2015).

50. Rogerson, M., Rohling, E. J., Bigg, G. R. \& Ramirez, J. Paleoceanography of the Atlantic-Mediterranean exchange: overview and first quantitative assessment of climatic forcing. Rev. Geophys. 50, RG2003 (2012).

51. McCave, I. \& Hall, I. Turbidity of waters over the Northwest Iberian continental margin. Prog. Oceanogr. 52, 299-313 (2002).

52. de Jesus Mendes, P. A., Maier, I. \& Thomsen, L. Effect of physical variables on particle critical erosion shear stress: hydrostatic pressure, slope and changes in water density. Estuar. Coast. Shelf. S. 75, 317-326 (2007).

53. de Stigter, H. C. et al. Recent sediment transport and deposition in the Lisbon-Setúbal and Cascais submarine canyons, Portuguese continental margin. Deep-Sea Res. Pt. II 58, 2321-2344 (2011).

54. Zahn, R. et al. Thermohaline instability in the North Atlantic during meltwater events: stable isotope and ice-rafted detritus records from Core SO75-26KL, Portuguese Margin. Paleoceanography 12, 696-710 (1997).

55. Incarbona, A. et al. Primary productivity variability on the Atlantic Iberian Margin over the last 70,000 years: evidence from coccolithophores and fossil organic compounds. Paleoceanography 25, PA2218 (2010).

56. Tjallingii, R. et al. Coherent high-and low-latitude control of the northwest African hydrological balance. Nat. Geosci. 1, 670-675 (2008).

57. Dubois-Dauphin, Q. et al. South Atlantic intermediate water advances into the north-east Atlantic with reduced Atlantic meridional overturning circulation during the last glacial period. Geochem. Geophys. Geosy. 17, 2336-2353 (2016)

58. Bao, R. et al. Widespread dispersal and aging of organic carbon in shallow marginal seas. Geology 44, 791-794 (2016).

59. McCave, I. N. \& Hall, I. R. Size sorting in marine muds: processes, pitfalls, and prospects for paleoflow-speed proxies. Geochem. Geophys. Geosy. 7, Q10N05 (2006).

60. Tesi, T., Semiletov, I., Dudarev, O., Andersson, A. \& Gustafsson, Ö. Matrix association effects on hydrodynamic sorting and degradation of terrestrial organic matter during cross-shelf transport in the Laptev and East Siberian shelf seas. J. Geophys. Res. -Biogeo. 121, 731-752 (2016).

61. Freitas, P. S. \& Abrantes, F. Suspended particulate matter in the Mediterranean water at the Gulf of Cadiz and off the southwest coast of the Iberian Peninsula. Deep-Sea Res. Pt. II 49, 4245-4261 (2002).

62. Davies, A. M., Xing, J., Huthnance, J. M., Hall, P. \& Thomsen, L. Models of near-bed dynamics and sediment movement at the Iberian margin. Prog. Oceanogr. 52, 373-397 (2002).

63. Epping, E., van der Zee, C., Soetaert, K. \& Helder, W. On the oxidation and burial of organic carbon in sediments of the Iberian margin and Nazaré Canyon (NE Atlantic). Prog. Oceanogr. 52, 399-431 (2002).

64. Sala, I., Caldeira, R., Estrada-Allis, S. N., Froufe, E. \& Couvelard, X. Lagrangian transport pathways in the northeast Atlantic and their environmental impact. Limnol. Oceanogr.: Fluids Environ. 3, 40-60 (2013)

65. Hernández-Molina, F. J. et al. Along-slope oceanographic processes and sedimentary products around the Iberian margin. Geo. -Mar. Lett. 31, 315-341 (2011).

66. Kim, J.-H. et al. Influence of deep-water derived isoprenoid tetraether lipids on the paleothermometer in the Mediterranean Sea. Geochim. Cosmochim. Ac. 150, 125-141 (2015).

67. Pénaud, A. et al. Assessment of sea surface temperature changes in the Gulf of Cadiz during the last $30 \mathrm{ka}$ : implications for glacial changes in the regional hydrography. Biogeosciences 8, 2295-2316 (2011).

68. Burdige, D. J. Preservation of organic matter in marine sediments: controls, mechanisms, and an imbalance in sediment organic carbon budgets? Chem. Rev. 107, 467-485 (2007). 
69. Shah, S. R., Mollenhauer, G., Ohkouchi, N., Eglinton, T. I. \& Pearson, A. Origins of archaeal tetraether lipids in sediments: insights from radiocarbon analysis. Geochim. Cosmochim. Ac. 72, 4577-4594 (2008)

70. Mollenhauer, G., Eglinton, T. I., Hopmans, E. C. \& Damsté, J. S. S. A radiocarbon-based assessment of the preservation characteristics of crenarchaeol and alkenones from continental margin sediments. Org. Geochem. 39, 1039-1045 (2008).

71. Quirós-Collazos, L. et al. Distribution and sources of organic matter in sizefractionated nearshore sediments off the Barcelona city (NW Mediterranean). Estuar. Coast. Shelf. S. 189, 267-280 (2017).

72. Pedrosa-Pàmies, R. et al. Composition and sources of sedimentary organic matter in the deep eastern Mediterranean Sea. Biogeosciences 12, 9935-9989 (2015).

73. Park, Y.-H. et al. Distribution, source and transportation of glycerol dialkyl glycerol tetraethers in surface sediments from the western Arctic Ocean and the northern Bering Sea. Mar. Chem. 165, 10-24 (2014).

74. Whitehouse, U. G., Jeffrey, L. M. \& Debbrecht, J. D. in Clays and Clay Minerals: Proceedings of the Seventh National Conference. 1-79 (Elsevier)

75. Stemmer, M., Gerzabek, M. H. \& Kandeler, E. Organic matter and enzyme activity in particle-size fractions of soils obtained after low-energy sonication. Soil Biol. Biochem. 30, 9-17 (1998).

76. Gibbs, R. J., Matthews, M. D. \& Link, D. A. The relationship between sphere size and settling velocity. J. Sediment. Res. 41, 7-18 (1971).

77. Xu, C., Guo, L., Dou, F. \& Ping, C.-L. Potential DOC production from sizefractionated Arctic tundra soils. Cold Reg. Sci. Technol. 55, 141-150 (2009)

78. Brodie, C. R. et al. Evidence for bias in $\mathrm{C}$ and $\mathrm{N}$ concentrations and $\delta^{13} \mathrm{C}$ composition of terrestrial and aquatic organic materials due to pre-analysis acid preparation methods. Chem. Geol. 282, 67-83 (2011).

79. Synal, H.-A., Stocker, M. \& Suter, M. MICADAS: a new compact radiocarbon AMS system. Nucl. Instrum. Meth. B 259, 7-13 (2007).

80. Wacker, L. et al. MICADAS: routine and high-precision radiocarbon dating. Radiocarbon 52, 252-252 (2010).

81. Soulet, G., Skinner, L. C., Beaupré, S. R. \& Galy, V. A note on reporting of reservoir ${ }^{14} \mathrm{C}$ disequilibria and age offsets. Radiocarbon 58, 205-211 (2016)

82. Stuiver, M., Reimer, P. \& Reimer, R. CALIB 7.1, program. Queens Univ., Belfast, UK. Available at http://radiocarbon.pa.qub.ac.uk/calib/ (2017).

83. Freeman, E., Skinner, L., Waelbroeck, C. \& Hodell, D. Radiocarbon evidence for enhanced respired carbon storage in the Atlantic at the Last Glacial Maximum. Nat. Commun. 7, 11998 (2016).

84. Rogerson, M., Rohling, E. J., Weaver, P. P. E. \& Murray, J. W. Glacial to interglacial changes in the settling depth of the Mediterranean Outflow plume. Paleoceanography 20, PA3007 (2005).

85. Clark, P. U. et al. The last glacial maximum. Science 325, 710-714 (2009).

86. Stanford, J. D. et al. Sea-level probability for the last deglaciation: a statistical analysis of far-field records. Glob. Planet. Change 79, 193-203 (2011).

\section{Acknowledgements}

We wish to thank Daniel Montluçon and Negar Haghipour for assistance with organic radiocarbon analyses, and Simon Crowhurst for down-core sediment XRF data. This work was made possible by a Marie Curie Actions postdoctoral fellowship to C.R.M and NERC support for cruise JC089 (NE/J00653X/1) to D.A.H. and L.S.

\section{Author contributions}

C.R.M. and T.I.E. conceptualized the project. L.S., D.A.H. and T.I.E. were among the principal investigators on cruise JC089. C.R.M., B.A., A.M.-G., G.H.H. and T.I.E. supervised and interpreted the radiocarbon analyses conducted by P.W. and C.M. D.A.H. and W.K. supervised X-ray fluorescence and lead-210 analyses, respectively. C.R.M., P.W., and B.A. wrote the manuscript with substantial contributions from C.M., L.S., D.A.H. and T.I.E. All authors reviewed the manuscript before submission.

\section{Additional information}

Supplementary Information accompanies this paper at https://doi.org/10.1038/s41467 018-06973-w.

Competing interests: The authors declare no competing interests.

Reprints and permission information is available online at http://npg.nature.com/ reprintsandpermissions/

Publisher's note: Springer Nature remains neutral with regard to jurisdictional claims in published maps and institutional affiliations.

\begin{abstract}
cc) (i) Open Access This article is licensed under a Creative Commons cc) Attribution 4.0 International License, which permits use, sharing, adaptation, distribution and reproduction in any medium or format, as long as you give appropriate credit to the original author(s) and the source, provide a link to the Creative Commons license, and indicate if changes were made. The images or other third party material in this article are included in the article's Creative Commons license, unless indicated otherwise in a credit line to the material. If material is not included in the article's Creative Commons license and your intended use is not permitted by statutory regulation or exceeds the permitted use, you will need to obtain permission directly from the copyright holder. To view a copy of this license, visit http://creativecommons.org/ licenses/by/4.0/.
\end{abstract}

(C) The Author(s) 2018 